CASE NOTE

\title{
ANUDO OCHIENG ANUDO V TANZANIA (JUDGMENT) (AFRICAN COURT ON HUMAN AND PEOPLES' RIGHTS, APP NO 012/2015, 22 MARCH 2018)
}

\author{
BRONWEN MANBY* \\ TABLE OF CONTENTS
}

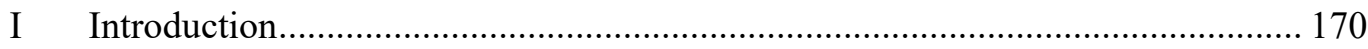

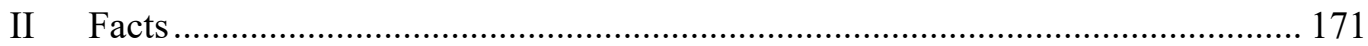

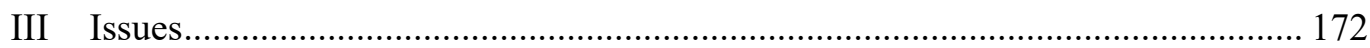

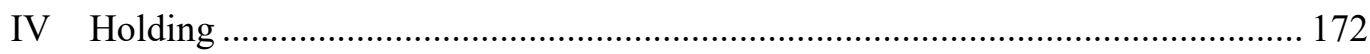

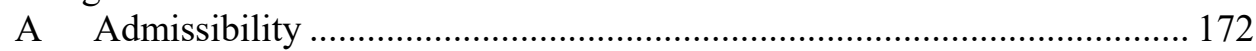

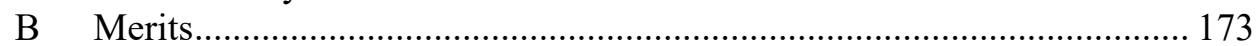

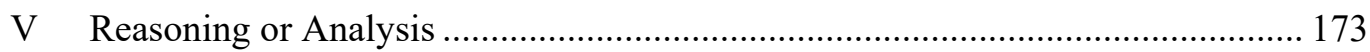

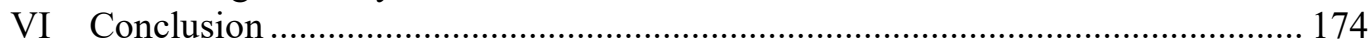

\section{INTRODUCTION}

Anudo Ochieng Anudo v Tanzania ('Anudo case') ${ }^{1}$ is the first case decided by the African Court on Human and Peoples' Rights ('African Court') that considers the right to a nationality. The judgment complements existing jurisprudence from the African Commission on Human and Peoples' Rights ('African Commission') and the African Committee of Experts on the Rights and Welfare of the Child. ${ }^{2}$ The African Court ruled that Tanzania had arbitrarily deprived the applicant of his nationality and then arbitrarily expelled him from the country.

Perhaps the most important aspect of the judgment was the holding that in the context where a person has previously been issued documents recognising nationality, the burden of proof falls on the state to prove that the applicant was not a national. ${ }^{3}$ A person must have the opportunity to make his or her case before an independent body, and decisions relating to nationality cannot be kept at the administrative level.

* Bronwen Manby is a senior policy and teaching fellow at the London School of Economics and Political Science, and an independent consultant. She previously worked for the Open Society Foundations and Human Rights Watch. She has written extensively on statelessness and the right to a nationality in Africa, and her book Citizenship in Africa: The Law of Belonging was published by Hart Publishing in November 2018.

1 (Judgment) (African Court on Human and Peoples' Rights, App No 012/2015, 22 March 2018) ('Anudo case').

2 See Bronwen Manby, Citizenship in Africa: The Law of Belonging (Hart 2018) ('Citizenship in Africa'); Bronwen Manby, Citizenship Law in Africa: A Comparative Study (Open Society Foundations, $\left.3^{\text {rd }} \mathrm{ed}, 2016\right)$.

3 Anudo case (n 1) 18 [80]. 
The African Court has jurisdiction to interpret any human rights obligations binding on the state, ${ }^{4}$ and the Anudo case thus draws not only on the African Charter on Human and Peoples' Rights ('ACHPR'), ${ }^{5}$ but also on the International Covenant on Civil and Political Rights ('ICCPR'), ${ }^{6}$ as well as art 15 of the Universal Declaration of Human Rights ('UDHR') ${ }^{7}$ — which the African Court affirmed to be customary international law. ${ }^{8}$

\section{FACTS}

Anudo Ochieng Anudo was born in 1979 in Butiama district, in the north-west of Tanzania. ${ }^{9}$ In 2012 , his passport was retained when he was seeking to register his marriage, on the grounds that there were doubts about his citizenship. ${ }^{10}$ In September 2013, he wrote to the Minister of Home Affairs and Immigration protesting the confiscation of his passport. ${ }^{11}$ In April 2014, the immigration service opened an investigation. ${ }^{12}$ A letter from the Minister dated 21 August 2014 informed the applicant that his passport had been cancelled on the ground that he was not a citizen. ${ }^{13}$

Unaware of the letter, the applicant went to the immigration office on 26 August 2014, hoping to recover his passport. ${ }^{14}$ Upon arrival he was arrested, detained and beaten. ${ }^{15}$ One week later, he was escorted to the Kenyan border and compelled to sign a notice of deportation and a document attesting that he was a Kenyan citizen. ${ }^{16}$

The applicant's father protested in writing to the Prime Minister, but the Minister of Home Affairs and Immigration confirmed the expulsion in December. ${ }^{17}$ In November, however, the Kenyan authorities declared the applicant to be in irregular status, and expelled him back to Tanzania - where he was not readmitted. ${ }^{18}$ Anudo then lived in 'no man's land' between Kenya and Tanzania for the next three years. ${ }^{19}$

The Tanzania Citizenship Act 1995 provides that the Minister's decision in relation to any application under the $A c t$ 'shall not be subject to appeal to or review

4 Protocol to the African Charter on Human and Peoples' Rights on the Establishment of an African Court on Human and Peoples' Rights, opened for signature 10 June 1998, OAU Doc OAU/LEG/EXP/AFCHPR/PROT(III) (entered into force 25 January 2004) art 3 ('ACHPR African Court Protocol'). African Charter on Human and Peoples' Rights, opened for signature 27 June 1981, 1520 UNTS 217 (entered into force 21 October 1986) ('ACHPR').

6 International Covenant on Civil and Political Rights, opened for signature 19 December 1966, 999 UNTS 171 (entered into force 23 March 1976) ('ICCPR').

7 Universal Declaration of Human Rights, GA Res 217A (III), UN GAOR, UN Doc A/810 (10 December 1948) ('UDHR').

$8 \quad$ Anudo case (n 1) 17 [76].

9 ibid 2 [1].

10 ibid 2 [4].

11 ibid 3 [5].

12 ibid 3 [6].

13 ibid 3 [8].

14 ibid 3 [9].

15 ibid.

16 ibid.

17 ibid 4 [10].

18 ibid 4 [11].

19 ibid 4 [12] (emphasis omitted). 
in any court'; 20 the Immigration Act 1995 similarly provides that in decisions relating to matters under the Act the Minister's 'decision shall be final'. ${ }^{21}$

In May 2015, the applicant emailed the African Court directly to seek its help, without legal advice. ${ }^{22}$ The application was registered and, after discussion by the African Court as to its validity, served on the respondent state. ${ }^{23}$ In early 2016, the African Court contacted Asylum Access Tanzania, which agreed to provide legal assistance to the applicant. ${ }^{24}$ In early 2017, the African Court also requested and subsequently received an amicus curiae brief from the Open Society Justice Initiative. ${ }^{25}$

\section{ISSUES}

The principal issues discussed in the Anudu case were the right to a nationality and not to be arbitrarily deprived of nationality; the right not to be expelled arbitrarily from a country; and the right to be heard by an impartial tribunal.

\section{HOLDING}

\section{A Admissibility}

Tanzania is one of only a handful of African states that have made the declaration provided for in the Protocol to the African Charter on Human and Peoples' Rights establishing the African Court to accept the right of individuals to petition the court directly. ${ }^{26}$ However, the government of Tanzania argued that the African Court should not accept jurisdiction on the grounds that: (i) the initial email from the applicant did not specify the legal instruments under which violations were alleged; ${ }^{27}$ (ii) he had not exhausted domestic remedies; ${ }^{28}$ and (iii) he had not filed his claim within a reasonable time. ${ }^{29}$

The African Court dismissed all three objections, on the following grounds: (i) the applicant's response to the state after he had legal advice had specified the claims made; ${ }^{30}$ (ii) the applicant had written to the Minister, which was the only administrative recourse available, and no court appeal was possible; 31 and (iii) the applicant had filed his complaint to the court within five months of receiving the Minister's letter — which itself was sent five months after he had complained to the Minister. ${ }^{32}$

20 Tanzania Citizenship Act 1995 (Tanzania) art 23.

21 Immigration Act 1995 (Tanzania) art 10(f). See also art 23.

22 Anudo case (n 1) 5 [15].

23 ibid 6 [16]-[17].

24 ibid 6 [19].

25 ibid 7 [24]-[25].

26 ACHPR African Court Protocol (n 4) art 34(6). As of September 2018, the states that have made the declaration are Benin, Burkina Faso, Côte d'Ivoire, Gambia, Ghana, Malawi, Mali, Tanzania and Tunisia.

ibid 11-13 [42]-[53].

ibid 13-14 [54]-[59].

ibid 9 [35].

ibid 12-13 [51]-[53].

ibid 14 [58]-[59]. 
The African Court confirmed longstanding African Commission jurisprudence that the existence of a legislative 'ouster clause' excluding court review meant that domestic remedies were by definition exhausted once any administrative review was complete. ${ }^{33}$

\section{B Merits}

The African Court held that:

(i) the deprivation of the applicant's nationality was arbitrary under art 15 of the UDHR; 34

(ii) his expulsion was therefore also arbitrary, and in violation of art 12 of the $A C H P R$ and art 13 of the ICCPR; 35 and

(iii) the applicant's right to due process protections had been violated, including the right to be heard before an impartial tribunal, under art 7 of the $A C H P R$ and art 14 of the ICCPR. ${ }^{36}$

The African Court ordered Tanzania to amend its legislation to provide individuals with judicial remedies in the event of a dispute over citizenship, and to take all necessary steps to restore the applicant's rights, including readmission to the country. ${ }^{37}$

The African Court reserved its ruling on other alleged violations, in order to consider them in a separate hearing to determine appropriate reparations, on the grounds that they were consequent on these primary violations. ${ }^{38}$

\section{REASONING OR ANALYSIS}

The African Court noted that there is no general provision on nationality in the $I C C P R$ or $A C H P R ;{ }^{39}$ however, it filled this gap by drawing on art 15(2) of the $U D H R$, which states that '[n]o one shall be arbitrarily deprived of his nationality'. ${ }^{40}$ In doing so, the African Court asserted (without discussion) that the $U D H R$ is part of customary international law, noting also a reference to the $U D H R$ in art 9(f) of the Constitution of Tanzania. ${ }^{41}$

Thus, while the African Court affirmed that the conferral of nationality is the sovereign right of states, it stated that international law permits loss of nationality only in 'very exceptional situations'. ${ }^{42}$ In addition to affirming a general obligation to avoid the risk of statelessness, ${ }^{43}$ the African Court drew on the 2013 report of the UN Secretary-General on human rights and arbitrary deprivation of

33 Bronwen Manby, 'Civil and Political Rights in the African Charter on Human and Peoples' Rights: Articles 1-7' in Malcolm Evans and Rachel Murray (eds), The African Charter on Human and Peoples' Rights: The System in Practice 1986-2006 (Cambridge University Press, $2^{\text {nd }}$ ed, 2008) 171. 
nationality 44 to state that the conditions to be fulfilled are: (i) a clear legal basis, (ii) a legitimate purpose conforming with international law, (iii) proportionality to the interest protected, and (iv) procedural guarantees allowing the person concerned to defend him or herself before an independent body. ${ }^{45}$

In considering whether these conditions had been fulfilled, the African Court held that:

since the Respondent State is contesting the Applicant's nationality held since his birth on the basis of legal documents established by the Respondent State itself, the burden is on the Respondent State to prove the contrary. ${ }^{46}$

It also endorsed the concept of a DNA test to prove the applicant's paternity. ${ }^{47}$

The African Court noted that the dual expulsion by both Tanzania and Kenya meant that Anudo was rendered stateless, and pointed out that the Tanzanian state 'could have satisfied itself that, if the Applicant is not Tanzanian, he is Kenyan'. ${ }^{48}$ However, the question as to whether or not Anudo was made stateless was not foundational to the African Court's reasons for finding Tanzania in breach of its obligations, which were rather based on respect for due process more generally. 49 The provisions excluding court review meant that the laws themselves, and not just the decision based upon them, were in violation of Tanzania's obligations. ${ }^{50}$

\section{CONCLUSION}

Although the $A C H P R$ does not mention the right to a nationality, the African Commission has accumulated significant jurisprudence. The number of cases brought to the African Commission reflects the fact that contested rights to belong to the national community have been at the basis of many of the most intractable political and military conflicts in the continent. ${ }^{51}$ Many of the African Commission's decisions have involved high profile individuals, often opposition politicians whose nationality is questioned by an incumbent government, most

44 Human Rights Council, Human Rights and Arbitrary Deprivation of Nationality: Report of the Secretary-General, UN GAOR, 25 ${ }^{\text {th }}$ sess, Agenda Items 2 and 3, UN Doc A/HRC/25/28 (19 December 2013).

45 Anudo case (n 1) 18 [79].

46 ibid 18 [80].

47 ibid 19 [86].

48 ibid 22 [102]-[103].

49 ibid 23 [105].

50 ibid 24 [113], 25 [116].

51 There is a large body of literature on this point. See, eg, Peter Geschiere and Stephen Jackson, 'Autochthony and the Crisis of Citizenship: Democratization, Decentralization, and the Politics of Belonging' (2006) 49(2) African Studies Review 1; Sara Dorman, Daniel Hammett and Paul Nugent (eds), Making Nations, Creating Strangers: States and Citizenship in Africa (Brill 2007); Morten Bøås and Kevin Dunn, Politics of Origin in Africa: Autochthony, Citizenship and Conflict (Zed Books 2013); Edmond J Keller, Identity, Citizenship, and Political Conflict in Africa (Indiana University Press 2014). 
famously Kenneth Kaunda of Zambia. ${ }^{52}$ Others have highlighted the concerns of groups facing systematic discrimination in their access to citizenship; ${ }^{53}$ or condemned mass expulsions in which little or no distinction has been made between nationals and non-nationals. ${ }^{54}$ The very first decision issued by the African Committee of Experts on the Rights and Welfare of the Child also concerned discrimination in nationality administration. ${ }^{55}$

In the Anudo case, the African Court made limited reference to these precedents, explicitly citing only a decision against Zambia. ${ }^{56}$ Perhaps most importantly, it did not endorse the now established position of the African Commission that 'a claim to citizenship or nationality as a legal status is protected under Article 5 of the Charter'. ${ }^{57}$ Although this point was argued by the Open Society Justice Initiative in its amicus brief, the reason for not addressing it may have been that a violation of art 5 was not asserted by Asylum Access in its initial submission on behalf of the applicant. ${ }^{58}$

The African Court thus missed an important opportunity to read the right to a nationality into the $A C H P R$ itself. Nonetheless, the assertion that the UDHR is customary international law, and in particular art 15 on the right to a nationality, ${ }^{5}$ is itself a welcome endorsement of a point more often argued by human rights lawyers than accepted by states.

52 African Commission on Human and Peoples' Rights, Communication No 211/98 (7 May 2001) ('Legal Resources Foundation v Zambia'). See also African Commission on Human and Peoples' Rights, Communication No 97/93 (6 November 2000) ('John K Modise v Botswana'); African Commission on Human and Peoples' Rights, Communication No 212/98 (5 May 1999) ('Amnesty International v Zambia'); African Commission on Human and Peoples' Rights, Communication No 246/02 (29 July 2008) ('Mouvement ivoirien des droits humains (MIDH) v Côte d'Ivoire'). The African Commission also ruled on similar issues in the case of a long-term resident married to a citizen: African Commission on Human and Peoples' Rights, Communication No 313/05 (26 May 2010) ('Kenneth Good v Republic of Botswana').

53 See African Commission on Human and Peoples' Rights, Communication No 317/06 (30 May 2016) ('Nubian Community in Kenya v Kenya'); African Commission on Human and Peoples' Rights, Communication No 318/06 (27 May 2016) ('Open Society Justice Initiative v Côte d'Ivoire').

54 See African Commission on Human and Peoples' Rights, Communication No 71/92 (31 October 1996) ('Rencontre Africain pour la Défense des Droits de l'Homme (RADDHO) v Zambia'); African Commission on Human and Peoples' Rights, Communication Nos 27/89, 46/91, 49/91 and 99/93 (31 October 1996) ('Organisation mondiale contre la torture and Others v Rwanda'); African Commission on Human and Peoples' Rights, Communication No 159/96 (11 November 1997) ('Union interafricaine des droits de l'Homme and Others $v$ Angola'); African Commission on Human and Peoples' Rights, Communication No 249/02 (7 December 2004) ('Institute for Human Rights and Development in Africa (on behalf of Sierra Leonean refugees in Guinea) v Republic of Guinea'); African Commission on Human and Peoples' Rights, Communication No 292/04 (22 May 2008) ('Institute for Human Rights and Development in Africa (on behalf of Esmaila Connateh \& 13 Others) v Angola').

55 African Committee of Experts on the Rights and Welfare of the Child, Communication No 002/2009 (22 March 2011) ('Institute for Human Rights and Development in Africa and Open Society Justice Initiative on behalf of Children of Nubian Descent in Kenya $v$ The Government of Kenya').

56 Anudo case (n 1) 24 [112], citing Amnesty International v Zambia (n 52). This case is not the Kaunda case, but contains similar facts relating to opposition politicians William Banda and John Chinula. Surprisingly, the Commission did not respond to an invitation to make a submission to the African Court on the Anudo case: at 6 [20].

57 Nubian Community in Kenya v Kenya (n 53) [140]. ACHPR (n 5) art 5 states that: 'Every individual shall have the right to the respect of the dignity inherent in a human being and to the recognition of his legal status. All forms of exploitation and degradation of man particularly slavery, slave trade, torture, cruel, inhuman or degrading punishment and treatment shall be prohibited'.

58 Anudo case (n 1) 4-5 [14].

59 ibid 17 [76]. 
Perhaps the most important of the African Court's contributions to international law in this field was its ruling on the burden of proof. In the vast majority of cases in Africa where citizenship of an individual has been contested, the government does not invoke formal deprivation procedures under the relevant law, but rather asserts that the person acquired nationality illegitimately. ${ }^{60}$ The advantage of this way of proceeding, from the government's perspective, is that fewer due process protections usually apply. The African Court outlaws this approach to circumventing the individual's rights by its holding that, if a person already holds official documents attesting citizenship, the state must prove (to the satisfaction of an independent tribunal) that he or she is not a citizen. ${ }^{61}$

In this regard, the African Court anticipated the June 2018 decision by the European Court of Human Rights in Alpeyeva and Dzhalagoniva v Russia. ${ }^{62}$ Though the facts appeared quite different - relating to access to Russian citizenship for ethnic Russian residents in other former Soviet Union states - one common feature was the question of whether denial that someone is entitled to nationality counts as deprivation of nationality. In Alpeyeva and Dzhalagoniva $v$ Russia, the European Court held that principles it had developed in previous cases on the right to private life apply equally to a state's assertion that a person has never acquired citizenship as they do to formal deprivation. 63

The African Court ordered Tanzania to amend its legislation - both the Immigration Act 1995 and the Tanzania Citizenship Act 1995 — to allow for court review of administrative decisions. ${ }^{64}$ While Tanzania's legislation is currently an outlier in Africa in completely excluding court review, the provisions reflect an ongoing tendency in former British territories in Africa (and Britain itself) to provide very wide discretion to the executive in relation to citizenship. ${ }^{65}$ The African Court's ruling opens potential avenues for further argument in both regional and national courts, and in parliaments, for this discretion to be restricted. Whether Tanzania itself will obey the Court's instructions is, however, doubtful during the administration of President John Magufuli, a head of state impatient of procedural requirements and court rulings. ${ }^{66}$

60 See Manby, Citizenship in Africa (n 2).

61 Anudo case (n 1) 18 [80].

62 Alpeyeva and Dzhalagoniva v Russia (European Court of Human Rights, Application Nos 7549/09 and 33330/11, 12 June 2018).

63 ibid. For commentary, see Katja Swider, 'ECHR Alpeyeva and Dzhalagoniya v Russia: Mass Confiscation of Passports Violates Article 8' (GLOBALCIT, 16 July 2018) $<$ http:/globalcit.eu/echr-alpeyeva-and-dzhalagoniya-v-russia-mass-confiscation-ofpassports-violates-article-8/>.

64 Anudo case (n 1) 28-29 [132].

65 See Manby, Citizenship in Africa (n 2) 126-46.

66 See, eg, 'Tanzania: Everyone is Scared' (African Arguments, 2 March 2018) $<$ https://africanarguments.org/2018/03/02/tanzania-everyone-is-scared/>. 